\title{
Migrants' pathways to aged care: the role of local relationships of care in facilitating access for super-diverse older populations
}

\author{
Hanna Carlsson (iD) \\ Institute of Management Research, Department of Geography, Planning and Environment, Radboud \\ University, Nijmegen, The Netherlands Email: h.carlsson@fm.ru.nl
}

(Accepted 29 July 2021)

\begin{abstract}
The literature on older migrants often focuses on identifying the characteristics of ethnic groups that constitute 'barriers' for members of these populations to access care. This paper offers an alternative conceptualisation of access to care, by combining relational approaches to place and the notion of super-diversity. From this perspective, 'access to care' is perceived as an outcome of an individual's embeddedness in relationships of care in urban places. The objective of the study is to identify relationships of care that facilitate access to aged care for older first-generation migrants. Thirty-two semi-structured interviews were conducted with older migrants who were residents of Nijmegen or The Hague, The Netherlands. All interviewees had accessed home care, home aid and/or day care. Both relationships with minority-specific services and informal relationships of care, particularly those within local minority communities, were found to facilitate access to aged care. Past experiences with health and social care were also found to influence current relationships with formal care providers. This study, therefore, suggests that policy makers and care organisations should build long-term positive relationships with new and incoming migrant groups. In addition, it argues that policy makers and care providers should identify locally relevant shared migration-related (rather than ethnic) identities around which communities can be mobilised and targeted with appropriate services.
\end{abstract}

Keywords: ageing and migration; health geography; older ethnic minorities; health and social care; relational approaches; super-diversity

\section{Introduction}

This paper explores how care providers and policy makers facilitate older migrants' access to care in cities. There is evidence that first-generation older migrants in North-Western Europe, North America and Australia face inequities in health and use of care services (de Valk and Fokkema, 2017; Karlis et al., 2018; van Gaans and Dent, 2018; Salma and Salami, 2020). Although older migrants in 
these regions tend to experience higher levels of ill-health, they are less likely to use aged-care services than their native-born counterparts (de Valk and Fokkema, 2017; Reus-Pons et al., 2017). Within the field of health geography, it is well known that city and neighbourhood of residence can influence care access (Macintyre et al., 2002; Tunstall et al., 2004; Cummins et al., 2007). However, gerontological researchers studying migrants' use of health and social care services have thus far paid scant attention to how the place of residence influences access to care. This paper begins to address this gap by presenting findings from 32 semi-structured interviews with older migrants who had accessed home care, home aid and/or day care. The interviews were conducted within the framework of a two-year (2017-2019) qualitative study on the organisation and delivery of aged care to older migrants in the cities of Nijmegen and The Hague, The Netherlands. The aim was to identify relationships of care in the two cities that facilitated older migrants' access to aged care.

To analyse the data, I draw together insights from health geography literature on relational approaches to place (Conradson, 2005; Cummins et al., 2007; Milligan and Wiles, 2010; Duff, 2011; Andrews et al., 2013) and scholarship in migration studies on the super-diversity of migrant populations (Vertovec, 2007; Boccagni, 2015; Bradby et al., 2017). While the former approach can be used to gain insight into how places can enable access to services and support, the latter can help to explain how migration-related variables shape whether and how a place enables access for individual migrants.

To answer the questions outlined above, the paper proceeds as follows. First, I outline the theoretical framework of the paper, arguing that a combination of superdiversity and relational approaches to place enables researchers to identify possibilities for greater equity of access to aged care in cities. After a review on the literature describing working-age and older migrants' access to care, I describe the study's comparative methodology and the analytical technique of mapping what Milligan (2009; Milligan and Wiles, 2010) terms 'landscapes of care'. The Findings section describes how a person's embeddedness in the local landscape of care can facilitate access to care services. Here, three types of relationships of care are discussed: those between individuals and minority-specific services, those within local communities of minorities, and historical relationships between care providers and minority groups. After showing how individual older migrants are embedded within these local relationships of care, it will be argued that variables of super-diversity are more useful than ethnicity in predicting for whom the care landscape in a city might enable access to care. The paper concludes with suggestions for how policy makers and care providers might improve aged-care access for migrants locally. These include (a) building longterm relationships of trust with new and incoming migrant groups and (b) using the technique of care landscape mapping to identify shared migration-related (rather than ethnic) identities around which communities can be mobilised and targeted with culturally, linguistically and/or religiously appropriate services.

\section{A relational place approach to investigating care access for super-diverse populations}

Within health geography, relational approaches to place have become increasingly common (Cummins et al., 2007; Milligan and Wiles, 2010; Duff, 2011; Andrews 
et al., 2013, 2014). Relational theories of place constitute a family of ideas rather than a single school of thought (for an overview, see Varró and Lagendijk, 2013). In this paper, I draw on emerging literature that analyses care as practices across the city (Power and Williams, 2020). In particular, I apply Milligan's (2009) 'landscape of care' approach to aged-care delivery.

From this 'landscape of care' perspective, places are conceptualised as configurations of formal and informal relationships of care, which can be organisational, social or embodied in nature, depending on which actors are involved in the specific relationship of care (Milligan and Wiles, 2010). While relationships of care can be spatially concentrated, they are not spatially confined. For example, informal social networks can stretch outside the confines of a city and even across national borders (Palladino, 2019). Furthermore, as pointed out by Dyck et al. (2005: 173), care and welfare organisations are always 'embedded in and constrained by policies and practices constructed at a scale beyond home' - in this case, the city. Drawing on Massey (1995), I further understand relationships of care to have a temporal dimension: histories of encounters with services, as well as reorganisations and policies all leave a legacy influencing current relationships of care.

Milligan's (2009) work is focused on the delivery of care to older adults living at home. Such delivery involves a range of actors, such as home care, home aid, health-care and welfare services, along with additional support from family, friends, neighbours and community groups. Because these actors often provide care in different places but are locally networked through their connections to each other and the older adults to whom they provide care, Milligan (2009; Milligan and Wiles, 2010) speaks of 'landscapes of care'. When coining the concept of landscapes of care, Milligan was primarily interested in how 'place shapes, and is actively shaped by, changing forms of care' (Milligan and Power, 2009: 579). In this paper, I am more interested in how people are embedded within the complex 'configurations' of relationships that constitute the care landscape.

Earlier research shows that this type of 'care landscape' approach is useful in investigating how migrants access care locally. Chakrabarti's (2010) study of access to pregnancy care in New York constitutes such an example. Through interviews with Bengali women, she found that social class, socio-economic status and length of residence in New York, more so than ethnicity, influenced the women's embeddedness in what Chakrabarti terms 'therapeutic networks'. Which types of formal and informal sources of care the women accessed depended on their embeddedness in the therapeutic network. Chakrabarti's (2010) study highlights how two individuals from the same ethnic background, living in the same place, can experience different 'socio-relational distances' to services, even when the physical distance is the same (Cummins et al., 2007).

To explain further how migration-related factors influence how individuals become embedded within their local landscape of care, and, hence, which sociorelational distance they experience to services, I have chosen to turn to the literature on super-diversity (Vertovec, 2007; Boccagni, 2015; Bradby et al., 2017). The term 'super-diversity' refers to the fact that migrant populations are highly diverse, not only in terms of countries of origin and ethnicity, but also in terms of language, religion, migration channels, immigration status, gender and age, all of which influence access to, and the need for, public services (Vertovec, 2007). In addition, 
Vertovec identifies place of residence as a factor of super-diversity. He points to how the degree of establishment of migrants from similar backgrounds influences the ease by which individual migrants become embedded in social networks and gain access to resources (Vertovec, 2007). The acknowledgement of the role that relationships between people and places have in facilitating or obstructing access to public services makes the super-diversity lens compatible with a relational approach to place.

Studies using a super-diversity lens tend to emphasise how individuals accessing care draw on a variety of resources in order to overcome any difficulties and barriers of access they might face (Green et al., 2014; Phillimore et al., 2018). The study by Green et al. (2014) on the 'pathways to care' of a super-diverse sample of care users in Sweden, Germany, the United Kingdom and Spain showed that most migrants drew on different forms of 'navigational support' to find their way within the health-care system. Navigational support could come from a variety of sources including religious organisations, charities focused on migrants, internet resources and members from the same minority group who were more familiar with the national care system. When support and/or health care was not available locally, some migrants drew on transnational networks and/or accessed care in other countries (Sime, 2014; Phillimore et al., 2018).

The studies discussed above mainly considered working-age migrants' access to health care. In comparison, very few studies use a super-diversity lens to study older migrants' processes of accessing aged care. However, research indicates that the process of accessing care might be different for people at a later stage in the lifecourse. Firstly, older migrants might draw on transnational networks differently than working-age migrants. What is more, transnational networks can lose importance with increasing age, both because of weakening ties in the country of origin and because of the loss of mobility often associated with old age (Heikkinen and Lumme-Sandt, 2013). Decreased mobility and a need for continuous hands-on care can also mean that travelling to receive care is not an option.

Secondly, for older migrants, experiences earlier in the lifecourse, both in the country of birth and the country of residence, influence how this group accesses aged care. A study on Turkish older people in Sweden indicates that early care encounters, e.g. with pregnancy care, can be important in shaping their later views on aged care (Naldemirci, 2013). Similarly, past experiences of racism and discrimination in encounters with health-care services can deter older migrants' use of aged-care services (Brotman, 2003).

Thirdly, older migrants' processes of accessing care are likely to involve considerations of filial piety. Norms regarding filial piety prescribe 'how family members are expected to care for and provide support to elderly family members' (Songur, 2019: 483). Some researchers find that many older migrants' views on filial piety change over time as a result of acculturation (Næss and Vabø, 2014; Liversage and Mizrahi Mirdal, 2017; Carlsson et al., in press). Older migrants may also adapt their expectations regarding filial piety in cases in which family care is not practically feasible (Giuntoli and Cattan, 2012; Næss and Vabø, 2014). While it is known that there is much diversity within older migrant populations in terms of norms of filial piety, little is known about how the place of residence might influence how such norms are negotiated. 
By reconceptualising migrants' access to aged care as an outcome of relationships of care in specific places, this paper responds to criticisms within the gerontological literature on older migrants and health inequality. Many scholars have argued that much of the gerontological literature relies on essentialist understandings of ethnicity, i.e. that ethnicity is seen as a fixed characteristic of a homogenous social group (Kramer and Barker, 1994; Koehn et al., 2013; Torres, 2015; Zubair and Victor, 2015). This conceptualisation is problematic in research on health inequalities since many of the identified 'barriers of access' faced by different ethnic minority groups are related to migration rather than culture per se. Such barriers include, for example, limited knowledge about the health-care systems, limited proficiency in the local language and low health literacy (de Graaff and Francke, 2009; Greenwood et al., 2015; Suurmond et al., 2016; Czapka and Sagbakken, 2020; Nielsen et al., 2021). Furthermore, by focusing largely on the failure of minority groups to access care, rather than on what care providers can do to improve accessibility, the responsibility for health inequalities is located with the group itself (Torres, 2019). By considering the role of place in facilitating access to care, and by broadening the focus from ethnicity to variables of super-diversity, this paper offers a way for researchers to shift focus from who 'older ethnic minorities are, and what they need, to what practitioners and policy makers can do to address these older people's needs' (Torres, 2019: 117).

While the notion of super-diversity challenges essentialist views on ethnicity, it can be criticised for failing to acknowledge the influence of unequal power structures that precede or trigger migration and migration-related health inequalities. As pointed out by Brotman (2003) and Hamed et al. (2020), racism in aged care and health care is a widespread issue. The reason I have nonetheless chosen to apply the concept of super-diversity is that my aim is to shed light on the dynamics which generate (in)equity of access to services locally. While carrying an awareness of wider structures of oppression, investigating how racism influences relationships with formal care is outside the paper's scope.

\section{Methodology}

This paper draws on findings from a qualitative study of the organisation and delivery of aged care to older migrants in the cities of Nijmegen and The Hague, The Netherlands. The cities of Nijmegen and The Hague were chosen because they have highly diverse populations (Jennissen et al., 2018), with migrants constituting 19 and 30 per cent of the older population (65+) in Nijmegen and The Hague, respectively. These cities were also selected because of the presence of minorityspecific services. These include intercultural elderly care advisors, and minorityspecific day care, home care and home aid.

The study is constituted by two case studies. Similarly to other comparative studies on super-diversity and place (Meissner and Vertovec, 2015; Padilla et al., 2015), the aim was to appreciate how variables of super-diversity play out in urban places, rather than to trace similarities and differences back to specific parameters, e.g. city size, demographic composition or individual characteristics like ethnicity. 


\section{Participant observation in day care centres and semi-structured interviews with older migrants}

I conducted 32 semi-structured interviews with first-generation older migrants who had access to health and social care. Most interviewees were recruited at day care centres, where I conducted participant observation as well as semi-structured interviews with staff to study minority-specific care practices. An overview of the data collected in the day care centres can be found in Table 1. While reference is made to these interviews and observations in this paper, the findings are discussed in more detail in Carlsson et al. (in press).

When recruiting older migrants for interviews, I sought to recruit as diverse a sample as possible regarding variables of super-diversity. Since the study was explorative in nature, I did not aim to achieve data saturation for specific categories of interviewees. Most interviewees were recruited at day care centres where I conducted participant observation within the framework of the larger study. All interviewees received a gift card in exchange for contributing their time and knowledge to the study. Since most of the day care centre clients were women, I also recruited male interviewees from a mosque in The Hague and a secular Turkish association in Nijmegen. Three of these interviewees had not yet accessed aged care. However, since they shared their considerations about aged care for the future, they are included in the sample. In total, I interviewed ten men and 22 women aged 55 and older. The interviewees were Dutch citizens and first-generation migrants from nine different countries of origin. Table 2 provides an overview of the interviewees' religious backgrounds, Dutch-language skills, migration trajectories and care use.

For conducting the interviews, I constructed an interview guide that was designed to elicit a narrative of how the interviewees accessed aged care. To this end, I asked them about their process of accessing care and which resources they drew on in doing so. The questions also covered past and current experiences with these services, along with past, current and future expectations and wishes regarding formal care and family care. All interviews were conducted by the author, except for three which were conducted by a student researcher. When necessary the interviews were conducted with the help of an interpreter. The interview guide, interview methods such as probing and the study's aims were discussed with all interpreters before the interview sessions. Where necessary, the questions were adapted to be culturally appropriate, in line with Bradby (2002). For example, we reflected together on whether using the word 'friends' or 'acquaintances' would be the most appropriate to elicit information about the interviewee's informal social networks. The interpreters were master's students, except in two cases: one in which I relied on assistance from a volunteer at one of the day care centres and one in which family members present wished to act as interpreters. In these cases, and similarly to Kosny et al. (2014), it was not possible to follow the above procedure, which may have compromised the quality of these particular interviews.

All segments of the interviews in which Dutch or English was spoken were transcribed verbatim. Where interviewees spoke at length followed by brief interpretations by the student assistants, the interpreter was asked to translate the sections. The reason that sections were left uninterpreted was often that the interpreters thought that the level of detail was too high. In several cases, the translation of 
Table 1. Overview of fieldwork in day care centres and meeting groups

\begin{tabular}{|c|c|c|c|}
\hline Organisation & Observations & $\begin{array}{l}\text { Interviews with } \\
\text { older migrants }\end{array}$ & Interviews with staff \\
\hline \multicolumn{4}{|l|}{ Nijmegen: } \\
\hline $\begin{array}{l}\text { Day care provider with } \\
\text { multicultural/Islamic profile }\end{array}$ & $27 \times 3$ hours & 5 & $\begin{array}{l}\text { Day care centre co-ordinator, } \\
\text { operational manager, Muslim } \\
\text { chaplain, manager }\end{array}$ \\
\hline $\begin{array}{l}\text { Day care provider with } \\
\text { Turkish profile }\end{array}$ & $6 \times 5$ hours & 3 & $\begin{array}{l}\text { Activity leader, day care } \\
\text { centre co-ordinator }\end{array}$ \\
\hline $\begin{array}{l}\text { Day care provider with } \\
\text { Indonesian group }\end{array}$ & $6 \times 7$ hours & 3 & Day care centre co-ordinator \\
\hline $\begin{array}{l}\text { Day care in Hatert } \\
\text { neighbourhood }\end{array}$ & $6 \times 8$ hours & 1 & \\
\hline Chinese meeting group & & 3 & \\
\hline $\begin{array}{l}\text { Secular Turkish meeting } \\
\text { group }\end{array}$ & & 2 & \\
\hline $\begin{array}{l}\text { Multicultural day care } \\
\text { provider }\end{array}$ & & 3 & \\
\hline Total number & 215 & & 7 \\
\hline \multicolumn{4}{|l|}{ The Hague: } \\
\hline $\begin{array}{l}\text { Day care provider with } \\
\text { groups with Hindustan, } \\
\text { Javanese and Chinese profile }\end{array}$ & $5 \times 6$ hours & 6 & $\begin{array}{l}\text { Day care co-ordinator, } \\
\text { manager }\end{array}$ \\
\hline $\begin{array}{l}\text { Culture-specific day care } \\
\text { group with Hindustan profile }\end{array}$ & $6 \times 7$ hours & 4 & Day care co-ordinator \\
\hline $\begin{array}{l}\text { Home care organisation with } \\
\text { multicultural profile }\end{array}$ & & 1 & Manager \\
\hline $\begin{array}{l}\text { Mainstream long-term care } \\
\text { provider with culture-specific } \\
\text { day care groups }\end{array}$ & & 0 & Day care co-ordinator \\
\hline Turkish mosque & & 2 & \\
\hline Total & & 32 & 5 \\
\hline Total hours of observation & 225 & & \\
\hline Total number of interviews & & & 12 \\
\hline
\end{tabular}

the uninterrupted sections afterwards added richness to the data. To prevent data misinterpretation, I also discussed the full transcripts with the interpreters and we clarified accordingly.

\section{Analysis: mapping landscapes of care}

To identify which relationships of care facilitated access to aged care in the two cities, and to investigate how super-diversity influenced these relationships, I used an analytical technique I term 'care landscape mapping' to map the care landscapes of 


\section{H Carlsson}

Table 2. Overview of the characteristics of the interviewees

\begin{tabular}{|c|c|}
\hline & $\mathrm{N}$ \\
\hline Total interviews & 32 \\
\hline \multicolumn{2}{|l|}{ Gender: } \\
\hline Male & 10 \\
\hline Female & 22 \\
\hline \multicolumn{2}{|l|}{ Age in years: } \\
\hline $60-69$ & 10 \\
\hline $70-80$ & 12 \\
\hline $81+$ & 10 \\
\hline \multicolumn{2}{|l|}{ Religion: } \\
\hline Muslim & 13 \\
\hline Christian & 3 \\
\hline Jehovah's Witness & 1 \\
\hline Hindustani & 3 \\
\hline No religion & 2 \\
\hline \multicolumn{2}{|l|}{ Not known } \\
\hline \multicolumn{2}{|l|}{ Country of birth: } \\
\hline Turkey & 11 \\
\hline Indonesia & 6 \\
\hline Suriname & 4 \\
\hline China and Hong Kong & 6 \\
\hline Iran & 1 \\
\hline Afghanistan & 1 \\
\hline Curaçao & 2 \\
\hline Saint Vincent and the Grenadines & 1 \\
\hline \multicolumn{2}{|l|}{ Migrant trajectory: } \\
\hline Labour migrant & 17 \\
\hline Post-colonial migrant & 13 \\
\hline Refugees & 2 \\
\hline \multicolumn{2}{|l|}{ Dutch skills: } \\
\hline Fluent & 16 \\
\hline Limited & 16 \\
\hline \multicolumn{2}{|l|}{ Health and social care accessed: } \\
\hline Social activities in community centre & 3 \\
\hline
\end{tabular}


Table 2. (Continued.)

\begin{tabular}{|c|c|}
\hline & $\mathrm{N}$ \\
\hline Minority-specific & 27 \\
\hline Mainstream & 1 \\
\hline \multicolumn{2}{|c|}{ Home care and/or domestic care: } \\
\hline Minority-specific & 8 \\
\hline Mainstream & 11 \\
\hline Considering aged care & 3 \\
\hline
\end{tabular}

the two cities. Here, 'mapping' refers to creating overviews of the places in which the interviewees lived, and of their embeddedness within them. By contrasting and comparing the interviewees' narratives of accessing care with the care landscape maps of Nijmegen and The Hague in mind, it was possible to pinpoint the interactions within relationships of care that made the biggest impact in terms of facilitating access to aged care.

Firstly, I mapped the care landscape for each city. This was done using municipal documents ${ }^{1}$ and a national overview of culture-specific health and social care providers. ${ }^{2}$ In addition to this, I also drew on interviews with 40 health and social care professionals, managers and policy advisors. The result can be found in Table 3. It should be noted that while I drew on interviews with health and social care professionals and managers to map the care landscape, I only touch upon the findings from these interviews briefly in the present paper since they are discussed in detail elsewhere (Carlsson and Pijpers, 2020, 2021).

Secondly, I mapped how the older migrants were embedded in the two landscapes of care. 'Embeddedness' refers to relationships of care with care and welfare professionals, care organisations, family members, friends, neighbours and members of local minority communities (Green et al., 2014; Palmberger, 2017). I first coded ways of accessing care, sources of navigational assistance and forms of care used. After that, I cross-tabulated sources of navigational support and informal care, as well as forms of formal care used against variables of super-diversity. The final table only includes the migration trajectory, place of residence, country of birth and Dutch-language proficiency, since these variables of super-diversity were found to influence the forms of care that an individual was using and the ways in which they accessed care.

In Table 4, interviewees are grouped based on their city of residence and migration trajectory. The table highlights that factors of super-diversity are better predictors of how care is accessed than ethnicity, but that even individuals with similar characteristics of super-diversity could still be differently embedded in the local landscape of care in terms of the types of care they used and the sources of navigational support to which they had access.

Finally, the last analytical step was to compare the narratives of the interviewees of labour and post-colonial migrants and refugees in each city, against the background of the care landscape maps. Through this process of comparison, it became possible to (a) pinpoint relationships of care that facilitated access to care and (b) to 


\begin{tabular}{|c|c|c|c|c|}
\hline $\begin{array}{l}\text { Population } \\
\text { composition }\end{array}$ & $\begin{array}{c}\text { Ethnic } \\
\text { composition of } \\
\text { older migrant } \\
\text { population }\end{array}$ & $\begin{array}{l}\text { Neighbourhood } \\
\text { characteristics }\end{array}$ & Minority-specific service provision & $\begin{array}{c}\text { Cultural/ethnic/religious } \\
\text { associations }\end{array}$ \\
\hline \multicolumn{5}{|l|}{ The Hague: } \\
\hline $\begin{array}{l}538,000 \text { residents of } \\
\text { whom } 14 \% \text { are aged } \\
65+. \text { Older } \\
\text { population consists } \\
\text { of } 32.9 \% \\
\text { first-generation } \\
\text { migrants }\end{array}$ & $\begin{array}{l}\text { Suriname } \\
(22.2 \%) \\
\text { Indonesia } \\
(22.4 \%) \\
\text { Germany }(12 \%) \\
\text { Morocco }(7.5 \%) \\
\text { Turkey }(6.9 \%) \\
\text { Antilles }(3.9 \%) \\
\text { Other }(37.1 \%)\end{array}$ & $\begin{array}{l}\text { Migrant populations } \\
\text { predominantly live in Laak, } \\
\text { Schilderswijk and } \\
\text { Transwaal; neighbourhoods } \\
\text { with a long history of in- } \\
\text { migration and diverse } \\
\text { populations }\end{array}$ & $\begin{array}{l}\text { - Intercultural elder-care } \\
\text { advisors (Cantonese, Berber } \\
\text { and Arabic, Turkish) } \\
\text { - Home care offered in different } \\
\text { languages/multicultural } \\
\text { profile } \\
\text { - Day care for Indonesian, } \\
\text { Chinese, Turkish, Moroccan, } \\
\text { Hindustani and multicultural } \\
\text { groups } \\
\text { - Residential care for Chinese, } \\
\text { Dutch-Indonesian, Moluccan, } \\
\text { Surinamese, Hindustani and } \\
\text { multicultural groups } \\
\text { - Co-housing for Chinese, } \\
\text { Turkish, Surinamese, } \\
\text { Surinamese-Creolean, } \\
\text { Surinamese-Javanese, } \\
\text { Hindustani, Antillean, } \\
\text { Dutch-Indonesian and } \\
\text { Moroccan groups }\end{array}$ & $\begin{array}{l}\text { - Hindustani temple; Hindustani } \\
\text { organisations; Surinamese } \\
\text { organisations; } \\
\text { Surinamese-Javanese } \\
\text { organisation } \\
\text { - Caribbean organisation } \\
\text { - Turkish mosques; women's } \\
\text { organisation; labour } \\
\text { organisation; cultural } \\
\text { organisation; Islamic } \\
\text { organisation; Kurdish } \\
\text { organisation; } \\
\text { Turkish-Azerbaijani } \\
\text { organisation } \\
\text { - Moroccan mosque; Moroccan } \\
\text { women's organisation; } \\
\text { Moroccan men's group } \\
\text { - Indonesian mosque; cultural } \\
\text { organisation; sport } \\
\text { organisation; music } \\
\text { organisation; Javanese } \\
\text { organisation } \\
\text { - Foundation The Chinese } \\
\text { Bridge } \\
\text { - Armenian; Ghanaian; } \\
\text { Sudanese; Papua New } \\
\text { Guinean; Somalian; Bulgarian; } \\
\text { African organisations }\end{array}$ \\
\hline
\end{tabular}




\section{Nijmegen:}

\begin{tabular}{|c|c|c|c|c|}
\hline $\begin{array}{l}175,000 \text { residents, of } \\
\text { whom } 15 \% \text { are aged } \\
65+. \text { Older } \\
\text { population consists } \\
\text { of } 20.0 \% \\
\text { first-generation } \\
\text { migrants }\end{array}$ & $\begin{array}{l}\text { Germany } \\
(41.9 \%) \\
\text { Indonesia } \\
(15.6 \%) \text { Turkey } \\
(7.4 \%) \\
\text { Morocco }(4.6 \%) \\
\text { Antilles }(2.8 \%) \\
\text { Suriname } \\
(3.4 \%) \\
\text { Other }(24.3 \%)\end{array}$ & $\begin{array}{l}\text { Migrant populations } \\
\text { dispersed across several } \\
\text { neighbourhoods and } \\
\text { surrounding villages, with } \\
\text { some concentration of } \\
\text { migrants in Neerbosch } \\
\text { Oest, Dukenburg, Oud-West } \\
\text { and Hatert }\end{array}$ & $\begin{array}{l}\text { - Intercultural elder-care } \\
\text { advisors (Berber and Arabic, } \\
\text { Turkish) } \\
\text { - Home care offered in Turkish } \\
\text { - Day care for Indonesian and } \\
\text { Turkish groups } \\
\text { - Chinese older people meeting } \\
\text { group } \\
\text { - Multicultural meeting group }\end{array}$ & $\begin{array}{l}\text { - Hindustani temple; } \\
\text { Surinamese group; } \\
\text { Surinamese Islamic group } \\
\text { - Antillean organisation } \\
\text { - Turkish mosques; Turkish } \\
\text { secular organisations; Turkish } \\
\text { Islamic organisation; Turkish } \\
\text { Alevi organisation } \\
\text { - Moroccan mosques; Moroccan } \\
\text { women's organisation } \\
\text { - Indonesian organisations; } \\
\text { Moluccan organisation }\end{array}$ \\
\hline
\end{tabular}

Source: Data on population composition were retrieved from a municipal overview of older migrants (Nijmegen, 2017, available upon request) and Ouderenmonitor 2018 (The Hague, 2018, https:// ckan.dataplatform.nl/dataset/dba52bda-3178-48f8-9b75-2faf4048d6d7/resource/8ee46bb8-c1a6-430f-9fce-e1b6615d1473/download/ouderenmonitor2018.pdf, accessed 1 July 2021). 
Table 4. Embeddedness in the care landscapes

\begin{tabular}{|c|c|c|c|c|c|c|c|c|c|c|c|c|c|c|c|c|c|c|c|c|c|c|c|}
\hline \multirow[b]{2}{*}{$\begin{array}{l}\frac{\grave{\nu}}{\text { है }} \\
\frac{\mathrm{E}}{3} \\
\bar{z}\end{array}$} & \multicolumn{2}{|c|}{ City } & \multicolumn{2}{|c|}{$\begin{array}{l}\text { Dutch } \\
\text { skills }\end{array}$} & \multicolumn{3}{|c|}{$\begin{array}{l}\text { Migrant } \\
\text { trajectory }\end{array}$} & \multicolumn{8}{|c|}{ Country of birth } & \multicolumn{5}{|c|}{$\begin{array}{c}\text { Sources of informal care and/or } \\
\text { navigational support }\end{array}$} & \multicolumn{3}{|c|}{$\begin{array}{l}\text { Aged-care } \\
\text { providers used }\end{array}$} \\
\hline & 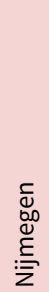 & 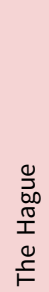 & . & 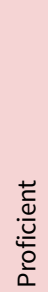 & 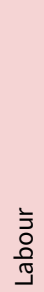 & 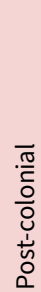 & 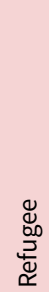 & 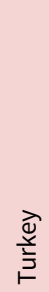 & 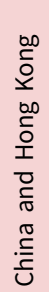 & 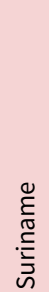 & 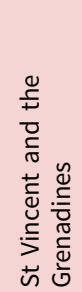 & 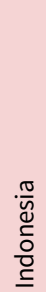 & $\begin{array}{l}\stackrel{0}{0} \\
\stackrel{0}{0} \\
\frac{0}{J}\end{array}$ & $\stackrel{ᄃ}{\stackrel{\widetilde{\pi}}{=}}$ & 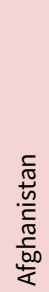 & 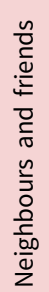 & 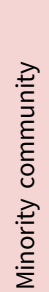 & 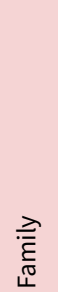 & 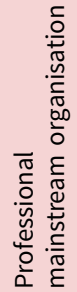 & 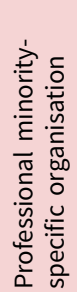 & 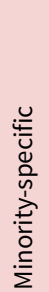 & 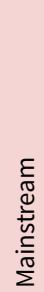 & $\cdot \stackrel{x}{\Sigma}$ \\
\hline
\end{tabular}

Labour migrants, Nijmegen:

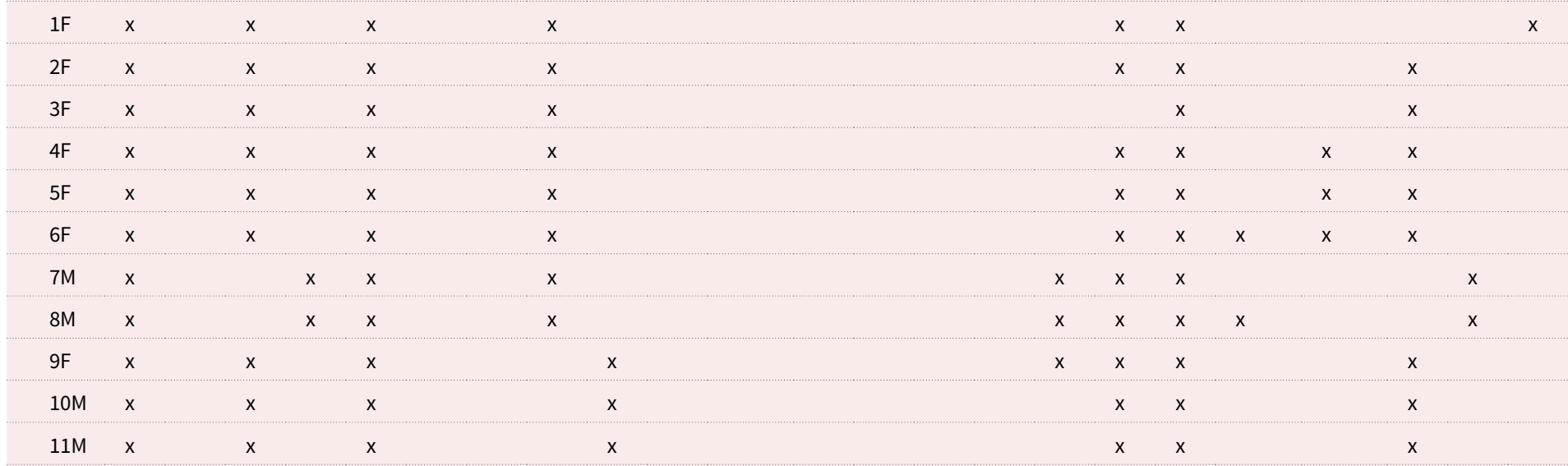

Labour migrants, The Hague:

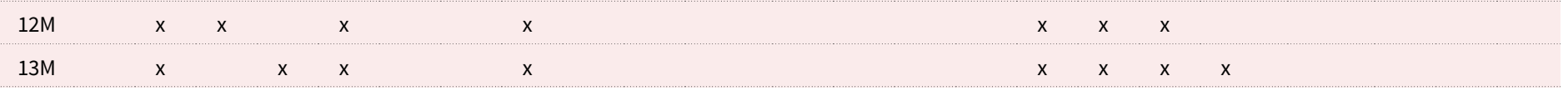




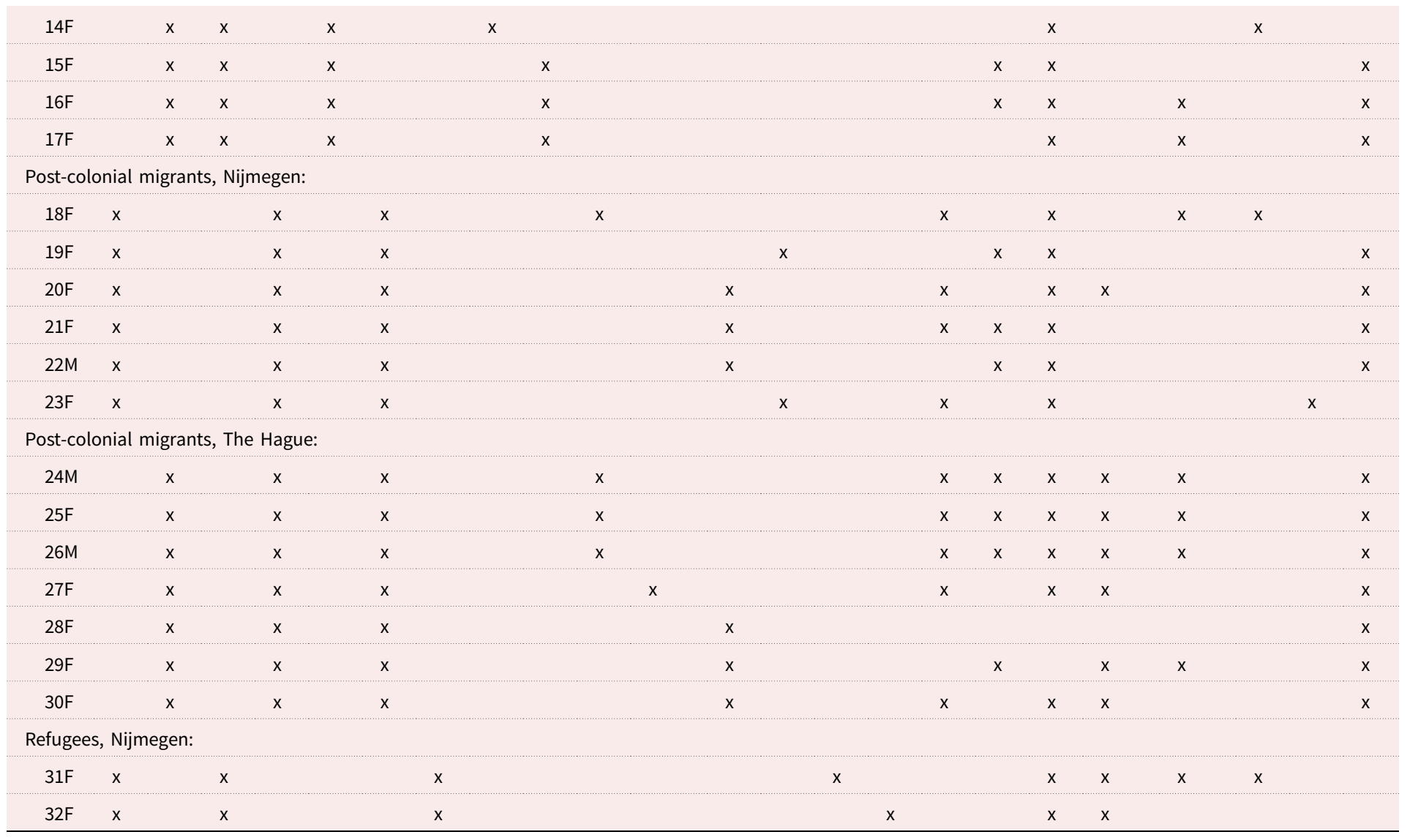


investigate how variables of super-diversity influenced an individual's embeddedness in these relationships of care.

\section{Findings}

\section{Navigating local landscapes of care: identifying relationships that matter}

The care landscapes of Nijmegen and The Hague differed regarding their specific configuration of organisational, social and embodied relationships of care. Nevertheless, the analysis of the older migrants' narratives reveals three relationships of care that facilitated access to aged care within both landscapes. These are relationships with minority-specific services, relationships within local minority communities and historical relationships with care providers. The embeddedness of the participants in their place of residence mattered as much as migration backgrounds when it came to how embedded individuals were in the landscape, and hence the degree of ease by which they accessed aged care. Certain characteristics known to be a barrier to access, such as low language proficiency, hindered access in the care landscape of one city but mattered little in another. In what follows, the multifaceted nature of the three relationships of care will be discussed, with reference to how they facilitated care in different ways depending on the characteristics of the local care landscape and the characteristics of the care-receiving group and/ or individual.

\section{'Minority-specific' services: reconfiguring relationships of care and migrants' shrinking socio-relational distance to services}

In the literature, minority-specific services, often referred to as 'ethno-specific' or 'minority-specific', are generally seen as facilitating access to aged care for older migrants (Ahaddour et al., 2016). However, this approach to service provision has also been criticised for being unfeasible for super-diverse populations (Phillimore et al., 2019). My findings show that these services were much more diverse in terms of clientele than labels like 'culturally specific' or 'ethno-specific' would indicate. Depending on the diversity and size of the local minority populations, different identities became significant as mobilising or dividing forces. For example, in The Hague, there were more internal divisions within the population of older people born in Indonesia than in Nijmegen, where this population was much smaller. Therefore, I refer to 'minority-specific' services. In this section, I describe the role that I found minority-specific aged-care services to play in the wider configuration of the local care landscape.

A closer look at the interactions that older migrants had with minority-specific services reveals that these services had two roles. Firstly, the services reconfigured the migrants' relationship with family care, by supporting the renegotiation of norms regarding family care and by offering a pragmatic alternative to the need for support and belonging. Secondly, minority-specific services diminished migrants' socio-relational distance to services by enabling direct interactions in migrants' preferred language and by offering more care choices to those with migration identities.

For older migrants belonging to well-established minority communities, furthermore, I found that minority-specific services reconfigured informal relationships of 
care by encouraging their clients to reinterpret their personal norms regarding filial piety (see also Carlsson et al., in press). Observations of interactions in the day care centres showed that staff used their intercultural competence to shift attitudes to formal care. An Islamic chaplain who organised weekly Quran readings explained that he found it his duty to inform the community that ensuring that one's parents receive formal care, done with 'professionalism and love', is an appropriate way to fulfil filial obligations. For some interviewees, though, accepting formal care was difficult and only took place gradually. The daughter of a Turkish home care recipient in The Hague described it as follows:

When we first requested home care she struggled with it, she felt that we abandoned her ... but now she is happy that we did it [organised home care]. (Daughter of female interviewee 14F)

When asked about the role of family members in care provision, some interviewees, like the woman in the above example, expressed that it was the duty of children to care for their parents (12M, 14F, 19F, 23F, 27F, 32F). Statements like the one below, from an Afghan woman who came to the Netherlands as a refugee, were not uncommon:

It is the duty of children to care for their parents because I and my husband have done so for them, so it is their duty to do it for us in return. (32F)

However, except in one case, the interviewees who expressed these views still received some form of aged care, indicating that abstract expectations of filial piety sometimes had to be adjusted to the actual ability of family members to provide aged care (Giuntoli and Cattan, 2012). The existence of minority-specific services can potentially facilitate such shifts in attitude, by creating a home-like environment. An Iranian woman, whose words are here paraphrased by the interpreter, described her minority-specific day care centre in the following way:

She feels at home because they are very friendly, it is like she comes to family members when she comes here, they care very well for her. (31F)

This experience stood in stark contrast to the interviewee's experience with a mainstream day care provider, where she felt excluded and discriminated against.

While some interviewees desired family care over formal care, this was not always the case. Several interviewees expressed a strong desire not to be a burden on family members when asked about care arrangements $(1 \mathrm{~F}, 4 \mathrm{~F}, 6 \mathrm{~F}, 9 \mathrm{~F}, 10 \mathrm{M}$, $11 \mathrm{M}, 18 \mathrm{~F}, 20 \mathrm{~F}, 21 \mathrm{~F}, 24 \mathrm{M}, 25 \mathrm{M}, 31 \mathrm{~F}$ ). This worry was mentioned by 12 interviewees with different ethnic, religious and migration backgrounds, indicating that acculturation to norms regarding filial piety and independence in old age was occurring across groups. For these older people, minority-specific services were an important resource in negotiating the need for social support in old age, against a backdrop of lowered expectations for their children to provide it.

A member of a Cantonese-speaking meeting group in Nijmegen illustrates this reconfiguration of informal care relationships. Referring to the decline of the 
custom of living with your children in old age in his community, he expressed a wish for a co-housing complex for Chinese people:

If the Dutch government could provide a house for Chinese people this would be the best case ... Because our children have already grown up and gone to live on their own. (10M)

The interviewee thus hoped that sharing his language and customs with co-residents would help him overcome social isolation, similar to Antilleans in Groningen (Lager et al., 2012), as well as provide a pragmatic solution to his care needs, considering his adjusted expectations of his children's ability to provide care.

In addition to helping local communities and individual older migrants to shift and renegotiate norms about filial piety, minority-specific services can diminish migrants' socio-relational distance to services. The availability of organisations with Turkish-speaking staff in Nijmegen enabled non-Dutch-speaking Turkish migrants and other non-Dutch speakers to make independent choices about formal care, which is illustrated by this quote from an interpreted interview with an older Turkish woman:

She knew for a long time that Multicare [an Islamic day and home care organisation] was here ... She says that she already knew Erkaslan [the manager of Multicare] and says that she called Erkaslan and told him that she wanted to come. $(4 \mathrm{~F})$

Many of the Turkish female interviewees (1F, 2F, 4F, 5F, 6F) in Nijmegen emphasised that it was their own choice to come to the day care centres they made use of. Several had contacted the organisation themselves to express their interest in day and/or home care $(4 \mathrm{~F}, 5 \mathrm{~F})$ or had been called by the director following a period of hospitalisation $(6 \mathrm{~F})$. One interviewee $(5 \mathrm{~F})$ also negotiated the hours of home care they received using these personal connections. Because of minority-specific services catering to the Cantonese- and Mandarin-speaking population, similar pathways to care were found among interviewees from China and Hong Kong in The Hague $(16 \mathrm{~F}, 17 \mathrm{~F})$. Thanks to the availability of services in their language, many interviewees are able to access services, despite facing significant barriers such as illiteracy and limited proficiency in the local language (Warnes et al., 2004).

Although minority-specific services can facilitate access, they can also create an overreliance on single relationships of formal care if options are limited. However, in this study, no interviewees raised this as a concern. This might be because most interviewees had access to several minority-specific providers. One interviewee (5F) arranged a work opportunity for her child in one minority-specific care organisation by promising to switch to a different minority-specific provider of day care if they would offer employment to her child in return. Other older people used the presence of other formal care organisations to compare the quality of care between mainstream and minority-specific care organisations. A Turkish woman (1F) using a day and home care provider focused on the Turkish community in Nijmegen 
explained that she had visited a Catholic residential care home for comparison and to prepare for her future care needs:

I want to see how they live, how they get good care in their language and culture ... it is important to see other places so that you can say [to the present, Turkish provider] this is good, or it is not, therefore it is good to have seen other places [for comparison]. (1F)

The above quote stands out because the interviewed woman had limited proficiency in Dutch. Nevertheless, having access to a wide range of care providers allowed her to make an independent decision about care. While the options were limited by her preference for culturally appropriate food and Turkish-speaking staff, she could, nevertheless, negotiate the quality of her care. Two Turkish men interviewed in the study, with good proficiency in Dutch, had a similar approach to choosing aged care. They preferred an organisation that could provide care in the Turkish language but weighed this criterion against both the quality of care and the experiences of friends (12M, 7M).

For older migrants who did speak Dutch fluently, minority-specific services were not necessary for access but were found to facilitate belonging (see also Carlsson et al., in press). An interview with an Indonesian man (23M) provided an example of how national identity can help a person orientate oneself in a new care landscape. The interviewee had recently moved to Nijmegen and attended both the Indonesian day care group and the activities of an Indonesian association. Although he still felt like an outsider to the Indonesian community in Nijmegen, these activities helped him orientate himself in his new hometown and gain access to informal social networks. Another interviewee $(21 \mathrm{~F})$, who, similarly to the Indonesian man, was proficient in Dutch and able to arrange care without navigational support, still chose to make use of minority-specific day care because it provided a sense of immediate belonging. She described her first experience with day care in the following way:

I was brought by the volunteers to the day care, we sat in the car, and straight away I could hear another client speak with the Indonesian accent, with Malay words in between, then I felt at home at once! (21F)

The Indonesian woman claimed, in contrast to the man in the previous example, that she 'would not go looking for' contact with other older people with Indonesian roots and she was not a member of any Indonesian cultural organisations. The example highlights that, for some interviewees, minority-specific care was one option of many, and, while not necessary for them to access care, could still be a means for them to forge connections and experience a sense of belonging.

As the above examples already indicate, the potential of minority-specific services to reconfigure and thicken relationships of care for any individual depended on the configuration of the local care landscape. Both in The Hague and Nijmegen, interviews with clients from the so-called Chinese day care and meeting group, respectively, revealed that clients were from Hong Kong and various regions of mainland China. Shared languages and/or cultural backgrounds were the common 
denominators rather than ethnicity or nationality. In the Hindustani day care group in The Hague, some clients were Muslim but shared their country of birth with other group members. Other members came from a different country but shared Caribbean culture with the Surinamese clients. The aforementioned examples highlight the many different common denominators that may draw clients together in minority-specific services, even when they are assumed to target specific ethnic groups.

Although many groups were composed of clients from different backgrounds, this was not always the case. Some identities were a cause for division rather than belonging. Which identities came to matter mostly depended on the characteristics of the local community. In the Indonesian day care group in Nijmegen, older people from different ethnic and racial backgrounds participated in the same day care group, and often bonded over words in Malay, 'indo music' and memories of Indonesia (fieldnotes, day care centre). In The Hague, which has a particularly large community of Dutch Indonesians, there were more divisions within the group along ethnic and religious lines. The organisation where I conducted participant observation offered one group for Javanese older people and one for Hindustani older people. Both groups had clients who had migrated from Indonesia. The reason there were two separate groups was that the Javanese older people were bullied by members of the other group, because of a belief that they belonged to a lower class in Indonesia (interview, day care co-ordinator). In Nijmegen, where there is a large Turkish community, the religious background was important; there were two day care organisations, one which was found to cater predominantly to Alevi Turkish people and older people from other Islamic countries, and one with clients who were Sunni Muslims. These examples highlight that to know for whom minority-specific services facilitate access to care, it is important to have an understanding of the social dynamics of the local care landscape of the city in question.

\section{Local (minority) communities: informal relationships of care as conduits to aged-care services}

Informal relationships of care, which can be defined as 'relations of trust and reciprocity associated with social capital' (Duff, 2011: 150, drawing on Portes, 1998) are known to enable health. Palmberger (2017) and Palaz (2020) both find that belonging to local minority communities is an important source of informal care and support for older migrants. The following section discusses how, and under which conditions, embeddedness in minority communities also facilitated access to aged care. I use the term 'minority communities' since the older migrants in the study often found connections through a range of identities, such as being a resident of a particular neighbourhood and/or a shared religion, culture or language.

One way in which being embedded in a minority community facilitated access to aged care was through relationships with care staff and managers with a shared minority background. Such relationships were particularly important for older people with low proficiency in Dutch. An older Turkish woman in Nijmegen exemplified this when stating how she had come to use home and day care provided by 
Multicare, a multicultural care organisation established by Dutch-Turkish secondgeneration migrants:

She knew for a long time that Multicare was here, and if you are part of the community, they will talk about it, at social events you hear it automatically. $(4 \mathrm{~F})$

Her experience was echoed by many of the other clients with a Turkish background. It should be noted that a strong local community might also present an obstacle for using formal care services, especially if filial care is the dominant norm. I found that professionals' attempts to expand clients' norms regarding filial piety to include formal care made the presence of large informal communities of people with a shared minority background an asset in broadening access to care (see also Carlsson et al., in press).

Another instance in which informal relationships of care functioned as conduits to formal care was when these relationships of care co-existed in the same physical location. A case in point is the narrative of one of the clients of the Hindustani day care group. He learnt about the day care groups because he often visited the community centre, and because he was acquainted with one of the clients:

I came to the community centre to read the newspaper and saw [an acquaintance]. We already knew each other, and he came in and saw me, greeted me and said, come along [to the day care group], so I did! (25M)

The day care group that this interviewee accessed, through his acquaintance, when visiting the local community centre was labelled as Hindustani/Surinamese by the elderly care advisor working in the community centre. However, during my participant observation in this day care centre, I found that clients in this day care group were, despite the name of the group, from different religious and ethnic backgrounds. The group included older people from Sint Maarten and Indonesia, as well as both Muslim and Hindustani Surinamese older people. All clients resided in the same neighbourhood in The Hague, where most had lived ever since they had arrived in the Netherlands. The neighbourhood had seen an influx of new migrant groups.. However, many of the interviewees' friends had stayed in the neighbourhood and regularly exchanged practical support $(27 \mathrm{M}, 28 \mathrm{~F})$. What is more, several had learnt about the group through each other, which, again, illustrates how informal and formal relationships of care can overlap in the context of minority communities.

While belonging to a local community often improved access to care, this was not always the case, particularly if members had low proficiency in Dutch and little formal education. An interviewee who regularly visited a Cantonese-speaking meeting group in Nijmegen told me that the members of the Chinese community in Nijmegen had a low education level and low proficiency in Dutch. He argued that this meant that they were poorly organised and were, therefore, struggling to make claims on minority-specific services:

It is not easy for us Chinese to have a community here, it is not easy to have this kind of organisation ... because we have a closed community. We don't have much 
contact with Dutch society, and we did not get an education, we have a low education level. (11M)

The group where I met this interviewee was organised by a social care worker. She had struggled to find a Cantonese-speaking volunteer to lead the group (informal interview with social worker). The difficulty of finding a volunteer reflects both the low education and limited Dutch skills of the first generation and the acculturation and low Cantonese skills of the second generation of Dutch-Chinese migrants (Bélanger and Verkuyten, 2010). Once established, the group strengthened its informal network in Nijmegen. Furthermore, care providers could reach the group with information about care services through outreach activities during informal meetings. However, the lack of both an informal organisation and minority-specific services with Cantonese-speaking staff still meant that members of the group could not access aged care easily.

While the Cantonese-speaking community in Nijmegen was weakly organised locally, this was not the case in The Hague. Because some of the Chinese older people had moved around the Netherlands before settling in Nijmegen, they had informal relationships of care that stretched across the country, in one case to The Hague. An interviewee explained that his friends in The Hague both told him about minority-specific services and offered to facilitate access for him by using their social network:

People in Nijmegen can also apply to live in Den Haag [The Hague], but sometimes the people from Den Haag will get the room first. His friend is a manager in Den Haag, and his friend once told him there is a room and asked whether he wanted to live there. (10M, conducted with an interpreter)

This particular interviewee chose to stay in Nijmegen, close to his children, like Turkish older people in Denmark (Liversage and Mizrahi Mirdal, 2017). Although this interviewee chose to stay, members of other groups did not. As pointed out by a member of the Hindustani community in Nijmegen, the lack of services and housing options that met the preferences of older people with a Hindustani background meant that many of these older people ended up moving to The Hague and Amsterdam:

Over the years, the need for [minority-specific] services for older people have grown [in Nijmegen]. But there were no such services here and they have not been developed ... So individual older people have not waited on policy, but have moved to places with more suitable services; The Hague was in the picture for Hindustani older people in Gelderland [the province in which Nijmegen is located]. There, there were already different 'specific' services for Hindustani older people, care homes, nursing homes, but also other extra-mural forms of care. (Email exchange, Hindustani community figure)

It was not only older Hindustani people in Nijmegen who had moved to The Hague to access services. A Muslim Surinamese woman who had lived happily in the Dutch rural province of Brabant for most of her adult life cited the presence of 
Surinamese mosques, a Muslim cemetery and a community with a shared minority background as reasons to move to The Hague:

I was the only Surinamese woman there [in Dongen, Brabant] ... And then you realise, you are getting older, and when I die I want to be buried according to my tradition. That is possible here in The Hague. There are many Islamic mosques here. For one person you are not going to make a fuss in a neighbourhood in Dongen, 'I want a mosque too'. No, I adapt to others, that is why I moved here. (26F)

These findings suggest that if there is a lack of services locally that meet religious, linguistic and/or cultural preferences, some older migrants may choose to relocate to care landscapes with minority-specific services and a larger minority community. Because informal relationships of care often stretch outside the spatial boundaries of municipalities, these bonds can function as conduits not only to local services but also to services elsewhere. This has implications for large super-diverse cities with many minority-specific services. As the older migrant population continues to grow in the coming years, some of these older migrants will likely move to cities where they can access services that meet their needs and preferences. It is questionable whether such migrations are desirable, as they might come at great personal cost to the older migrants and their families.

\section{Historical relationships with formal care providers and minority associations}

When comparing the interviewees' narratives of accessing care, it became clear that relationships of care could often be traced back in time. Experiences with health and social care services earlier in life, both in their country of birth and in the immigration country, were found to influence the level of trust that individuals had in aged-care services. In addition, it was found that the history of relationships between formal care providers and minority associations can also influence access to care for entire migrant groups.

Interviews with older migrants who came to The Hague after Suriname ceased to be a Dutch colony constitute an example of how the experience of care and welfare services upon arrival affects individuals' relationships to care services in the present. When interviewed, several of the Surinamese interviewees, unprompted, emphasised the support they had received from social workers when they arrived in the Netherlands and during their first years there, e.g. support to find housing $(25 \mathrm{M}, 26 \mathrm{~F}, 27 \mathrm{M})$. The narrative of one of the interviewees exemplifies these positive first encounters with social care providers:

Someone from the social services guided us through the process, took us to view houses. I said I don't need to look, it is good if it is in Brabant [a Dutch region]. It was very beautiful when the houses were finished, those had been furnished for us. (26F)

The narrative of this interviewee highlights how 'structural forces that occur over an extended period of time intersect with individual life trajectories' and continue to shape relationships of care into the present (Ferrer et al., 2017: 15). The quoted woman was not the only one with this experience, other interviewees who came 
to The Hague after Suriname ceased to be a Dutch colony also brought up positive experiences with social care services in the past and also expressed trust in services in the present. For example, a male interviewee of Surinamese origin emphasised the importance of asking for help from welfare services: 'You have to make your problems known, you have to get informed, then you get a solution' (25M). These examples highlight how support at the time of arrival can create relationships of trust with formal care providers which are sustained over time.

Just as positive early encounters can facilitate access to aged care later in life, negative experiences of racism and discrimination can hinder it (Ferrer et al., 2017). In the present study, no interviewees mentioned racism when asked about negative experiences with aged-care providers. However, some interviewees spoke of communication difficulties $(1 \mathrm{~F}, 9 \mathrm{~F})$ and a feeling of not being listened to (12M). Despite difficulties with communication, a female interviewee expressed gratitude towards care services:

You should not complain about care ... for [older] migrants, in general, it is difficult. We need a lot of care and we cannot express it very well, so we are a difficult group, but that does not mean we should criticise too much, they do their job. (1F)

These findings echo results from a study on migrants' unsatisfactory experiences with the Swedish health-care system, in which migrant women were found to express gratitude for the care they received, despite having unsatisfactory experiences with some services (Bradby et al., 2020).

Thus far, the discussion has focused on how individual experiences with health and social care services throughout the lifecourse can generate trust in services in the present. However, this was not the only way in which past experiences concerning relationships of care could facilitate, or obstruct, access to care. Another historical care relationship that was found to be important in facilitating access was that between care organisations and minority communities. The case of the so-called Hindustani day care group in The Hague illustrates this point.

The day care group had originally been established by the Hindustani neighbourhood organisation to allow older members to meet. Some years later, a mainstream care provider offered to facilitate the meetings. The group began to meet in the community centre and a woman with a Surinamese background was hired to co-ordinate the group's activities (27M; interview, day care co-ordinator). In addition to facilitating activities, the day co-ordinator engaged in outreach during festivities organised by the neighbourhood organisation for Hindustani people (interview, day care co-ordinator). Interviews with several of the day care co-ordinators and activity leaders of other groups revealed that outreach activities were common practice. Ongoing relationships between care providers and minority associations can thus facilitate older migrants' access to aged-care services.

It should be noted that these relationships do not always have to be between specific care providers and minority associations. In Nijmegen, I found evidence that the presence of historical relationships between local care professionals and specific minority communities facilitated access to care. During the study, a multicultural residential care home and day care centre which primarily targeted Turkish older people in Nijmegen closed its doors. In response, a mainstream social care 
organisation started a Turkish day care group (informal interview, staff member of a mainstream care organisation). This new initiative is evidence of well-established relationships between professionals, older people and informal organisations. Communities that care professionals have experience reaching are more likely to continue to receive minority-specific care in the future, which, as mentioned above, is known to facilitate access to aged-care services. For example, the daughter of an interviewee (14F) heard about home care for the first time at a women's group in a multicultural neighbourhood in The Hague:

I was at a women's group, they gave information, and then I thought, this is something for my mother, and then we came to [minority-specific day care provider]. (Daughter of 14F)

The fact that well-established communities with existing relationships with care organisations are more likely to access care also sheds light on the position of older migrants belonging to smaller and/or less-established minorities locally. Individuals from smaller or recently arrived minorities, such as Iranians in both Nijmegen and The Hague (interview, social worker, Nijmegen; interview, elderly care advisor, The Hague), are likely to have low access to care both because of a higher likelihood of limited proficiency in the majority language and because of a lower likelihood of a well-established minority community.

\section{Increasing older migrants' access to care in urban places}

Drawing on the findings from this study, several suggestions can be made for what policy makers and care providers could do to address local inequalities in access to and use of aged care. Studies on inequalities in access to care faced by older migrants often call for more services that better meet older migrants' cultural and linguistic preferences (Koehn, 2009; Ahaddour et al., 2016). This study confirms that what is here termed 'minority-specific' services do facilitate access. It also brings nuance to the understanding of how and for whom these services are beneficial. For older people with little proficiency in the local language and/or a large socio-relational distance to mainstream services, minority-specific services facilitate the negotiation of norms regarding filial piety and/or enable older migrants to be more independent in arranging their care. For older migrants who were proficient in Dutch, the existence of minority-specific services was not a prerequisite for accessing care, but an option that promoted their sense of belonging and facilitated connection to informal networks. Some researchers in the field of health and social care have been sceptical of minority-specific services that target ethnic groups, as it is not considered feasible to provide such services to superdiverse populations (Phillimore et al., 2019). This study refutes this criticism, by showing that most minority-specific groups gather clients from more diverse backgrounds than might be expected. The findings highlight that a shared place identity (i.e. a common place of residence), religious background and/or language can constitute unifying factors for aged-care services. This insight is significant since it opens possibilities for service providers to target groups with multiple shared backgrounds, in some cases drawing on already-existing communities. 
While the descriptions of the situation of different migrant groups in relation to aged care are specific to the two case studies, the method of care landscape mapping can be used to tailor service provision in other cities. Policy makers and care providers are advised to map the local landscape, by using and/or producing overviews of existing services and the different local communities, drawing on census data and the local knowledge of care workers and minority associations. While the study shows that ethnicity is a poor proxy for an older person's ability to access aged care, it does show that a person's ethnic, cultural and religious background can indicate their embeddedness in the local landscape of care. For example, older people belonging to locally small minorities or older people who have migrated recently are more likely to struggle both to access care and to find care options that meet their preferences. By establishing and continuously updating their knowledge about the make-up of the care landscape, care providers and policy makers can begin to think creatively about how to reach individuals from groups with a large socio-relational distance to aged-care services.

Apart from providing a method for analysing access to care locally, the paper sheds light on how the local configuration of relationships of care stretches over time and space. Experiences with health and social care services earlier in the lifecourse can either serve to narrow or increase the socio-relational distance to services in the present. For that reason, it is important to support migrants when they arrive, as positive first encounters can establish a relationship of trust with formal care (Naldemirci, 2013). While immigration policies often are decided on the national level, policy makers at the urban level can still incorporate recommendations and funding for health and social care workers to invest in building relationships with minority communities in local policies (Carlsson and Pijpers, 2021).

By seeing urban places as configurations of informal and formal relationships of care, the study highlights that informal networks of care can function as conduits for accessing formal care. If there are minority-specific services in a particular city, being part of a well-organised minority group in that city often means that one has connections to providers targeting minorities, through staff and managers with a shared background. Whether minority-specific services exist locally or not, communities that are well established are more often subject to outreach activities by care workers, which can also narrow the socio-relational distance to care services (see also Carlsson and Pijpers, 2020). Policy makers and care providers are, therefore, encouraged both to support existing communities and to look for opportunities to mobilise communities of older people that are currently weakly embedded in informal networks. Because informal networks can stretch outside the boundary of the local care landscape, such relationships of care can also facilitate access to care services in other cities. As the population of older migrants grows, it can, therefore, be expected that cities with well-established minority communities and large numbers of minority-specific services will see increased pressure on the latter.

\section{Conclusion}

Older people with a migration background constitute a growing and increasingly diverse population in many immigration countries in Europe and North America (de Valk and Fokkema, 2017; Karlis et al., 2018; van Gaans and Dent, 2018; 
Salma and Salami, 2020). Despite a growing awareness of the barriers that members of this population might face in accessing care, older migrants continue to experience inequities in access to and use of care. The ambition of this paper was to offer an analytical framework that provides insight into what facilitates access to care where it takes place: in the cities and neighbourhoods where these older people live. To this aim, it offers a framework that combines relational approaches to place (Milligan, 2009; Milligan and Power, 2010; Milligan and Wiles, 2010; Power and Williams, 2020) with the notion of super-diversity (Vertovec, 2009; Boccagni, 2015; Bradby et al., 2017). From this perspective, access to aged care is perceived as an outcome of an individual's embeddedness in a local configuration of relationships of care, which is spatially concentrated in, but not confined to, the city. By shifting the focus from characteristics of ethnic groups to how variables of super-diversity play out in local landscapes of care, the paper responds to criticisms of gerontological research on older migrants' access to care, which is accused of relying on simplified notions of ethnicity (Kramer and Barker, 1994; Koehn et al., 2013; Torres, 2015; Zubair and Victor, 2015).

While the paper draws on findings from a larger study on aged-care provision for older migrants in the Dutch cities of Nijmegen and The Hague (see also Carlsson and Pijpers, 2020, 2021), the focus, here, is on the narratives of 32 older migrants who had accessed home care, home aid or day care. Most of these interviewees were accessed via minority-specific day care providers. It can be argued that this recruitment strategy gives a limited view of the care landscapes in question. However, it should be noted that this strategy was adopted because very few older migrants used mainstream care providers. Nevertheless, interviews with a larger number of older migrants using mainstream services might generate new insights into how these providers can facilitate access to care.

Although the older immigrants' narratives were central to the analysis, the aim of the study was to generate insight into how care providers and policy makers can facilitate access to care for those older migrants who continue to experience a large socio-relational distance to services. The study shows that by using local knowledge to mobilise and service migrant communities around the most suitable shared identities in a particular city, policy makers and care providers can take concrete steps to address health inequities at the urban level. Such local strategies do not address the structural inequalities and injustices that contribute to the health inequalities experienced by older migrants and minorities (MacLeavy, 2008). However, local measures can still constitute a step towards greater justice, which is why I argue that they are both needed and worthwhile (Rosenberg, 2014).

Acknowledgements. Many thanks to all interviewees who gave me their trust and shared their stories with me: there would be no research without you. I am also indebted to all interpreters, who did a fantastic job at interpreting the interviews, sometimes for the first time. I am very grateful for the support of Marijke Pijnappels, who conducted three of the interviews with the older migrants within the framework of her dissertation project: it was a pleasure to work with you. When writing the paper, I was a visiting doctoral student at the Welfare and Lifecourse group at the Department of Sociology at Uppsala University. Many thanks to the members of the research group who commented on earlier versions of this paper. In particular, I would like to thank Prof. Sandra Torres who supervised me during my time at Uppsala University and provided both support and inspiration to sharpen my analysis. Thanks also to Dr Roos Pijpers, Dr Kai Whiting, Dr Rianne van Melik and Prof. Huib Ernste, who commented on drafts of the paper. Last but 
not least, I am grateful to the anonymous reviewers whose comments were very helpful in the process of improving the paper.

Ethical standards. No ethical approval was required for this study.

\section{Notes}

1 The municipal overview of minority self-organisations was provided by a social worker in Nijmegen and the municipal overview of migrant organisations was retrieved from https://www.socialekaartdenhaag.nl/ zoek/migrantenorganisaties (accessed 6 March 2020).

2 The national overview of day care, co-housing and residential care was published by Kennisplatform Integratie en samenleving in 2017 and retrieved from https://www.kis.nl/sites/default/files/bestanden/ Publicaties/lijst-woongroepen-verpleeghuizen-dagbesteding-ouderen-met-migratieachtergrond.pdf (accessed 6 March 2020).

\section{References}

Ahaddour C, van den Branden S and Broeckaert B (2016) Institutional elderly care services and Moroccan and Turkish migrants in Belgium: a literature review. Journal of Immigrant and Minority Health 18, 1216-1227.

Andrews GJ, Evans J and Wiles JL (2013) Re-spacing and re-placing gerontology: relationality and affect. Ageing \& Society 33, 1339-1373.

Andrews GJ, Chen S and Myers S (2014) The 'taking place' of health and wellbeing: towards nonrepresentational theory. Social Science \& Medicine 108, 210-222.

Bélanger E and Verkuyten M (2010) Hyphenated identities and acculturation: second-generation Chinese of Canada and the Netherlands. Identity 10, 141-163.

Boccagni P (2015) (Super) diversity and the migration-social work nexus: a new lens on the field of access and inclusion? Ethnic and Racial Studies 38, 608-620.

Bradby H (2002) Translating culture and language: a research note on multilingual settings. Sociology of Health \& Illness 24, 842-855.

Bradby H, Green G, Davison C and Krause K (2017) Is super-diversity a useful concept in European medical sociology? Frontiers in Sociology 1, The article number is 17.

Bradby H, Humphris R and Padilla B (2020) Universalism, diversity and norms: gratitude, healthcare and welfare chauvinism. Critical Public Health 3, 166-178.

Brotman S (2003) The limits of multiculturalism in elder care services. Journal of Aging Studies 17, $209-229$.

Carlsson H and Pijpers R (2020) Working towards health equity for ethnic minority elders: spanning the boundaries of neighbourhood governance. Journal of Health Organization and Management 35, 212-228.

Carlsson H and Pijpers R (2021) Diversity-mainstreaming in times of ageing and migration: implementation paradoxes in municipal aged care provision. Journal of Ethnic and Migration Studies 47, 2396-2416.

Carlsson H, Pijpers R and van Melik R (in press) Day-care centres for older migrants: spaces to translate practices in the care landscape. Social \& Cultural Geography. Available online doi:10.1080/14649365.2020.1723135.

Chakrabarti R (2010) Therapeutic networks of pregnancy care: Bengali immigrant women in New York City. Social Science \& Medicine 71, 362-369.

Conradson D (2005) Landscape, care and the relational self: therapeutic encounters in rural England. Health \& Place 11, 337-348.

Cummins S, Curtis S, Diez-Roux AV and Macintyre S (2007) Understanding and representing 'place' in health research: a relational approach. Social Science \& Medicine 65, 1825-1838.

Czapka EA and Sagbakken M (2020) 'It is always me against the Norwegian system.' Barriers and facilitators in accessing and using dementia care by minority ethnic groups in Norway: a qualitative study. BMC Health Services Research 20, The article number is 954.

de Graaff FM and Francke AL (2009) Barriers to home care for terminally ill Turkish and Moroccan migrants, perceived by GPs and nurses: a survey. BMC Palliative Care 8, 3.

de Valk $\mathbf{H}$ and Fokkema T (2017) Health among older populations of migrant origin. In Apt W (ed.), Demographic Change and Migration. The Hague: Joint Programming Initiative (JPI) 'More Years, Better Lives', pp. 40-52. 
Duff C (2011) Networks, resources and agencies: on the character and production of enabling places. Health \& Place 17, 149-156.

Dyck I, Kontos P, Angus J and McKeever P (2005) The home as a site for long-term care: meanings and management of bodies and spaces. Health \& Place 11, 173-185.

Ferrer I, Grenier A, Brotman S and Koehn S (2017) Understanding the experiences of racialized older people through an intersectional life course perspective. Journal of Aging Studies 41, 10-17.

Giuntoli G and Cattan M (2012) The experiences and expectations of care and support among older migrants in the UK. European Journal of Social Work 15, 131-147.

Green G, Davison C, Bradby H, Krause K, Mejías FM and Alex G (2014) Pathways to care: how superdiversity shapes the need for navigational assistance. Sociology of Health \& Illness 36, 1205-1219.

Greenwood N, Habibi R, Smith R and Manthorpe J (2015) Barriers to access and minority ethnic carers' satisfaction with social care services in the community: a systematic review of qualitative and quantitative literature. Health \& Social Care in the Community 23, 64-78.

Hamed S, Thapar-Björkert S, Bradby H and Ahlberg BM (2020) Racism in European health care: structural violence and beyond. Qualitative Health Research 30, 1662-1673.

Heikkinen SJ and Lumme-Sandt K (2013) Transnational connections of later-life migrants. Journal of Aging Studies 27, 198-206.

Jennissen R, Engbersen G, Bokhorst M and Bovens M (2018) De nieuwe verscheidenheid: De toegenomen diversiteit naar herkomst in Nederland. The Hague: Wetenschappelijke Raad voor het Regeringsbeleid (WRR).

Karlis G, Stratas A, Locke M, Gravelle F and Arora G (2018) Serving the health care and leisure needs of ethnic aged in Canada: implications and concerns. Physical Culture and Sport: Studies and Research 80, 5-14.

Koehn S (2009) Negotiating candidacy: ethnic minority seniors' access to care. Ageing \& Society 29, 585-608.

Koehn S, Neysmith S, Kobayashi K and Khamisa H (2013) Revealing the shape of knowledge using an intersectionality lens: results of a scoping review on the health and health care of ethnocultural minority older adults. Ageing \& Society 33, 437-464.

Kosny A, MacEachen E, Lifshen M and Smith P (2014) Another person in the room: using interpreters during interviews with immigrant workers. Qualitative Health Research 24, 837-845.

Kramer BJ and Barker JC (1994) Ethnicity in the elderly. Journal of Cross-cultural Gerontology 9, 403-417.

Lager D, van Hoven B and Meijering L (2012) Places that matter: place attachment and wellbeing of older Antillean migrants in the Netherlands. European Spatial Research and Policy 19, 81-94.

Liversage A and Mizrahi Mirdal G (2017) Growing old in exile - a longitudinal study of migrant women from Turkey. Journal of Ethnic and Migration Studies 43, 287-302.

Macintyre S, Ellaway A and Cummins S (2002) Place effects on health: how can we conceptualise, operationalise and measure them? Social Science \& Medicine 55, 125-139.

MacLeavy J (2008) Managing diversity? 'Community cohesion' and its limits in neoliberal urban policy. Geography Compass 2, 538-558.

Massey D (1995) Places and their pasts. History Workshop Journal 39, 182-192.

Meissner F and Vertovec S (2015) Comparing super-diversity. Ethnic and Racial Studies 38, 541-555.

Milligan C (2009) There's No Place Like Home: Place and Care in an Ageing Society. Farnham, UK: Ashgate.

Milligan C and Power A (2009) The changing geography of care. In Brown T, McLafferty S and Moon G (eds), A Companion to Health and Medical Geography. Chichester, UK: Blackwell Publishing, pp. 567-586.

Milligan C and Wiles J (2010) Landscapes of care. Progress in Human Geography 34, 736-754.

Naldemirci O (2013) Caring (in) Diaspora: Aging and Caring Experiences of Older Turkish Migrants in a Swedish Context. Gothenburg, Sweden: University of Gothenburg.

Nielsen TR, Nielsen DS and Waldemar G (2021) Barriers in access to dementia care in minority ethnic groups in Denmark: a qualitative study. Aging \& Mental Health 25, 1424-1432.

Næss A and Vabø M (2014) Negotiating narratives of elderly care: the case of Pakistani migration to Norway. Ageing International 39, 13-32.

Padilla B, Azevedo J and Olmos-Alcaraz A (2015) Super-diversity and conviviality: exploring frameworks for doing ethnography in Southern European intercultural cities. Ethnic and Racial Studies 38, 621-635.

Palaz FS (2020) The social networks and engagements of older Turkish migrants in Germany. Open Journal for Sociological Studies 4, 79-92. 
Palladino S (2019) Older migrants reflecting on aging through attachment to and identification with places. Journal of Aging Studies 50, 100788.

Palmberger M (2017) Social ties and embeddedness in old age: older Turkish labour migrants in Vienna. Journal of Ethnic and Migration Studies 43, 235-249.

Phillimore J, Bradby H, Knecht M, Padilla B and Pemberton S (2018) Bricolage as conceptual tool for understanding access to healthcare in superdiverse populations. Social Theory \& Health 17, 231-252.

Phillimore JA, Bradby H and Brand T (2019) Super-diversity, population health and health care: opportunities and challenges in a changing world. Public Health 172, 93-98.

Portes A (1998) Social capital: its origins and applications in modern sociology. Annual Review of Sociology 24, 1-24.

Power ER and Williams MJ (2020) Cities of care: a platform for urban geographical care research. Geography Compass 14, 1.

Reus-Pons M, Kibele EUB and Janssen F (2017) Differences in healthy life expectancy between older migrants and non-migrants in three European countries over time. International Journal of Public Health 62, 531-540.

Rosenberg M (2014) Health geography I: social justice, idealist theory, health and health care. Progress in Human Geography 38, 466-475.

Salma J and Salami B (2020) 'We are like any other people, but we don't cry much because nobody listens': the need to strengthen aging policies and service provision for minorities in Canada. The Gerontologist 60, 279-290.

Sime D (2014) 'I think that Polish doctors are better': newly arrived migrant children and their parents' experiences and views of health services in Scotland. Health \& Place 30, 86-93.

Songur W (2019) Older migrants' use of elderly care in Sweden: family affects choice between home help services and special housing. European Journal of Social Work 24, 481-491.

Suurmond J, Rosenmöller DL, el Mesbahi H, Lamkaddem M and Essink-Bot M-L (2016) Barriers in access to home care services among ethnic minority and Dutch elderly-a qualitative study. International Journal of Nursing Studies 54, 23-35.

Torres S (2015) Expanding the gerontological imagination on ethnicity: conceptual and theoretical perspectives. Ageing \& Society 35, 935-960.

Torres S (2019) Ethnicity and Old Age: Expanding Our Imagination. Bristol, UK: Policy Press.

Tunstall HV, Shaw M and Dorling D (2004) Places and health. Journal of Epidemiology \& Community Health 58, 6-10.

van Gaans D and Dent E (2018) Issues of accessibility to health services by older Australians: a review. Public Health Reviews 39, 20.

Varró K and Lagendijk A (2013) Conceptualizing the region - in what sense relational? Regional Studies $47,18-28$.

Vertovec S (2007) Super-diversity and its implications. Ethnic and Racial Studies 30, 1024-1054.

Warnes AM, Friedrich K, Kellaher L and Torres S (2004) The diversity and welfare of older migrants in Europe. Ageing \& Society 24, 307-326.

Zubair M and Victor C (2015) Exploring gender, age, time and space in research with older Pakistani muslims in the United Kingdom: formalised research 'ethics' and performances of the public/private divide in 'the field'. Ageing \& Society 35, 961-985.

Cite this article: Carlsson H (2021). Migrants' pathways to aged care: the role of local relationships of care in facilitating access for super-diverse older populations. Ageing \& Society 1-28. https://doi.org/10.1017/ S0144686X21001240 